\title{
Pengaruh Disiplin Kerja, Lingkungan Kerja dan Kompensasi Terhadap Kinerja Pegawai di Universitas Medan Area
}

\author{
Agus Salim Harahap \\ STIE Deli Sumatera, Medan, Indonesia \\ Email: aguss1816@gmail.com
}

\begin{abstract}
Abstrak-Penelitian ini dilakukan untuk mengetahui Pengaruh Disiplin Kerja, Lingkungan Kerja Dan Kompensasi Terhadap Kinerja Pegawai Di Universitas Medan Area. Penelitian ini menggunakan metode kuantitatif dengan jumlah sampel sebanyak 50 pegawai dari berbagai unit dengan menggunkan alat Analisis Regresi Linier Berganda. Hasil dari penelitian ini adalah Terdapat pengaruh yang tidak signifikan antara Disiplin Kerja terhadap Kinerja Pegawai. Terdapat pengaruh yang tidak signifikan antara Lingkungan Kerja terhadap Kinerja. Terdapat pengaruh yang signifikan antara Kompensasi terhadap Kinerja Pegawai. Secara simultan terdapat pengaruh yang signifikan antara Disiplin Kerja, Lingkungan Kerja dan Kompensasi secara bersama-sama terhadap kinerja karyawan Koefisien determinasi (Rsqure) sebesar 0,575 dan nilai (Adjusted R Square) yaitu 0,547 atau 54,7\% artinyavariabel (DisiplinKerja, Lingkungan Kerja dan Kompensasi), penelitian mampu menjelaskan tentang Kinerja Pegawai sebesar 54,7\% sedangkan sisanya 45,3\% dipengaruhi oleh variabel lain diluar penelitian ini seperti variabel gaya kepemimpinan, motivasi kerja, kepuasan kerja, dan iklim kerja.
\end{abstract}

Kata Kunci: Disiplin Kerja; Lingkungan Kerja; Kompensasi; Kinerja

\begin{abstract}
This study was conducted to determine the effect of work discipline, work environment and compensation on employee performance at the University of Medan Area. This study uses a quantitative method with a sample of 50 employees from various units using the Multiple Linear Regression Analysis tool. The results of this study are that there is an insignificant effect between Work Discipline on Employee Performance. There is an insignificant effect between the Work Environment on Performance. There is a significant influence between compensation on employee performance. Simultaneously there is a significant influence between Work Discipline, Work Environment and Compensation together on employee performance. The coefficient of determination (Rsqure) is 0.575 and the value (Adjusted R Square) is 0.547 or $54.7 \%$ meaning the variables (Work Discipline, Work Environment and Compensation) ), the study was able to explain the employee performance by $54.7 \%$ while the remaining $45.3 \%$ was influenced by other variables outside this study such as leadership style variables, work motivation, job satisfaction, and work climate.
\end{abstract}

Keywords: Work Discipline; Work Environment; Compensation; Performance

\section{PENDAHULUAN}

Karyawan merupakan penggerak utama sumberdaya lainya yang terdapat dalam organisasi. Perkembangan organisasi tidak terlepas dari peranan karyawan dalam organisasi, organisasi harus dapat mengoptimalkan kinerja karyawan sehingga memberikan kontribusi optimal dalam peningkatan kinerja organisasi secara keseluruhan. Salah satu cara yang dapat dilakukan organisasi adalah menerapkan disiplin kerja dan kompensasi yang adil dan layak dan lingkungan kerja yang nyaman dan aman.

Adapun yang menjadi masalah dalam hal ini adalah berdasarkan pengamatan peneliti diketahui bahwa kurangnya tertibnya pegawai dalam menggunakan jam kerja yang mengakibatkan menurunnya kinerja sehingga membuat pekerjaan menumpuk tidak selesai tepat waktu, hal ini terjadi karena pegawai sering molor masuk kantor dan lebih dulu dikantin dengan menghabiskan waktu mengobrol sesama rekan kerja setelah absen. Sedangkan dalam hal absensi sudah menggunakan alat elektronik sesuai dengan ketentuan peraturan organisasi, yang menjadi ukuran masuk tidaknya seorang pegawai. Permasalahan lain yang ditemukan adalah lingkungan kerja antara sesama pegawai yang kurang terjalin hubungan yang membuat lingkungan kerja jadi tidak nyaman, yang mana munculnya perkumpulan dan kelompok-kelompok para pegawai, berkurangnya kekeluargaan yang selama ini sudah begitu indah dan nyaman, yang mana akan mempengaruhi kinerja pegawai dan kenyamanan dan emosi yang akan menurunkan prestasi kerja. Dan adanya pembiaran dari pimpinan membuat hal ini semakin menimbulkan penurunan kinerja.

Permasalahan lain yang ditemukan adalah kurangnya pemberian kompensasi yang dilakukan organisasi kepada pegawai seperti, pemberian bonus dan penghargaan untuk pegawai yang berprestasi kurang diperhatikan, sehingga prestasi kerja atas hasil kerja yang mereka tunjukkan dan yang sudah dicapai pegawai sesuai dengan waktu yang telah ditetapkan menjadi menurun, yang akhirnya berdampak pada penurunan kinerja pada pegawai yang mana berprestasi atau tidak berprestasi sama saja tidak mendapat penghargaan yang mengakibatkan turunya kinerja karyawan.

\section{KERANGKA TEORI}

\subsection{Kinerja}

Menurut Mondy (2008:256) menerangkan kinerja adalah hasil kerja seseorang karyawan selama periode tertentu dibandingkan dengan berbagai kemungkinan misalnya standar target, sasaran atau kriteria yang telah ditentukan terlebih dahulu dan disepakati bersama. Menurut Mahsum (2009:25) kinerja adalah gambaran mengenai tingkat pencapaian pelaksanaan suatu kegiatan/program/kebijakan dalam mewujudkan sasaran, tujuan, misi dan visi yang tertuang dalam startegic planing. 


\subsection{Disiplin Kerja}

Simamora (2006:238), disiplin kerja adalah sebuah proses yang digunakan untuk menghadapi permasalahan kinerja, proses ini melibatkan manajer dalam mengidentifikasikan dan mengkomunikasikan masalah-masalah kinerja kepada para pegawai. Sedangkan menurut Ardhana (2011:134), disiplin kerja merupakan suatu sikap menghormati, menghargai, patuh, dan taat terhadap peraturan-peraturan yang berlaku, baik yang tertulis maupun tidak tertulis serta sanggup menjalankannya dan tidak mengelak untuk menerima sanksi-sanksinya.Pendapat-pendapat tersebut memberikan penegasan bahwa disiplin merupakan faktor yang sangat penting dalam perkembangan karakteristik kepribadian seorang karyawan seperti tanggung jawab, percaya diri, ketekunan dalam bekerja dan kontrol diri serta dapat mempertahankan dan mengembangkan perilaku yang tepat dalam bekerja.

\subsection{Lingkungan Kerja}

Sunyoto (2013:43), mendefinisikan pengertian lingkungan kerja adalah segala sesuatu yang ada di sekitar para pekerja dan yang dapat mempengaruhi dirinya dalam menjalankan tugas-tugas yang dibebankan. Kemudian Sedarmayanti (2009:121), mengatakan, lingkungan kerja adalah keseluruhan alat perkakas dan bahan yang dihadapi, lingkungan sekitarnya dimana seseorang bekerja, metode kerjanya, serta pengaturan kerjanya baik sebagai perseorangan maupun sebagai kelompok.

\subsection{Kompensasi}

Menurut Hasibuan (2012:118) kompensasi adalah semua pendapatan yang berbentuk uang, barang langsung atau tidak langsung yang diterima karyawan sebagai imbalan atas jasa yang diberikan kepada perusahaan. Mathis dan jackson (2009:118) mengemukakan bahwa "kompensasi merupakan faktor penting yang mempengaruhi bagimana dan mengapa orang-orang bekerja pada suatu organisasi lainya. Sastro hardi wiryo (2007:181) menyatakan bahwa "kompensasi adalah imbalan jasa atau balas jasa yang diberikan oleh perusahaan kepada para tenaga kerja, karena tenaga kerja telah memberikan sumbangan tenaga dan pikiran demi kemajuan perusahaan guna mencapai tujuan yang telah ditetapkan.

\section{METODOLOGI PENELITIAN}

Penelitian ini bertujuan untuk mencari hubungan sebab akibat antara dua variabel atau lebih dari beberapa populasi atau sampel dengan teknik pengambilan sampel secara random dan menggunakan instrumen penelitian dalam pengumpulan data untuk menguji hipotesis/dugaan yang telah ditetapkan dengan beberapa pertanyaan/angket. populasi dalam penelitian ini adalah pegawai Fakultas Psikologi, Fakultas Ekonomi dan Bisnis, Fakultas Teknik, BAK dan BAA yang berjumlah 50 orang sehingga semua populasi menjadi objek penelitian. Instrumen dalam penelitian yang digunakan adalah kuesioner, dengan analisis data yang digunakan adalah analisis regresi berganda (multiple regretion).

\section{HASIL DAN PEMBAHASAN}

\section{a. Pengaruh DisiplinKerjaTerhadap Kinerja Pegawai}

Menurut Ardhana (2011:134), disiplin kerja merupakan suatu sikap menghormati, menghargai, patuh, dan taat terhadap peraturan-peraturan yang berlaku, baik yang tertulis maupun tidak tertulis serta sanggup menjalankannya dan tidak mengelak untuk menerima sanksi-sanksinya.Pendapat-pendapat tersebut memberikan penegasan bahwa disiplin merupakan faktor yang sangat penting dalam perkembangan karakteristik kepribadian seorang karyawan seperti tanggung jawab, percaya diri, ketekunan dalam bekerja dan kontrol diri serta dapat mempertahankan dan mengembangkan perilaku yang tepat dalam bekerja. Dengan adanya tata tertib yang ditetapakan, dengan tidak sendirinya para pegawai akan mematuhinya, maka perlu bagi pihak organisasi mengkondisikan pegawainya dengan tata tertib kantor. Untuk mengkondisikan pegawai agar bersikap disiplin. Disiplin kerja adalah suatu sikap perilaku yang dilakukan seacara sukarela dan penuh kesadaran dan keadaan untuk mengikuti peraturan yang ditetapkan perusahaan baik tertulis maupun tidak tertulis . Hilangnya disiplin akan berpengaruh terhadap efisiensi kerja dan efektivitas kerja tugas pekerjaan. Bilamana kedisiplinan tidak dapat ditegakkan maka kemungkinan tujuan yang telah ditetapkan tidak dapat dicapai secara efektif dan efisien.

\section{b. Pengaruh Lingkungan Kerja Terhadap Kinerja Pegawai}

Menurut Mardiana (2005:74) "Lingkungan kerja adalah lingkungan dimana karyawan melakukan pekerjaanya seharihari”. Lingkungan kerja yang kondusif memberikan rasa aman dan memungkinkan para karyawan untuk dapat bekerja optimal. Lingkungan kerja dapat mempengaruhi emosi pegawai. Jika pegawai menyenangi lingkungan kerja dimana dia bekerja, maka pegawai tersebut akan betah di tempat kerjanya untuk melakukan aktivitas sehingga waktu kerja dipergunakan secara efektif dan optimis prestasi kerja pegawai juga tinggi. Lingkungan kerja tersebut mencakup hubungan kerja yang terbentuk antara sesama pegawai dan hubungan kerja antar bawahan dan atasan serta lingkungan fisik tempat karyawan bekerja. Dengan menjaga kondisi lingkungan kerja yang ada, hal tersebut akan mendorong rasa nyaman di dalam bekerja sehingga kualitas pekerjaan menjadi maksimal untuk mencapai hasil sesuai dengan tujuan sehingga dapat diharapkan dengan lingkungan kerja yang baik dapat meningkatkan kinerja karyawan. Lingkungan kerja 
dalam suatu perusahaan mempunyai arti penting bagi pegawai yang bekerja di dalamnya, karena lingkungan ini akan mempengaruhi secara langsung maupun tidak langsung pegawai yang ada di dalamnya. Lingkungan kerja dalam suatu perusahaan sangat penting untuk diperhatikan manajemen. Lingkungan kerja yang kondusif dapat memusatkan konsentrasi karyawan dan meningkatkan kinerja karyawannya.

\section{c. Pengaruh Kompensasi Terhadap Kinerja Pegawai}

Menurut Hasibuan (2012: 118) "kompensasi adalah semua pendapatan yang berbentuk uang, barang langsung atau tidak langsung yang diterima karyawan sebagai imbalan atas jasa yang diberikan kepada perusahaan. Adanya sistem kompensasi yang baik pada suatu organisasi diharapkan dapat meningkatkan kinerja para karyawan.Apabila karyawan mendapat tambahan kompensasi dari organisasi, maka cenderung akan berusaha untuk meningkatkan kinerjanya. Jika karyawan merasa imbalanya yang diterimanya telah sebanding dengan kontribusi yang diberikan, maka karyawan akan berusaha untuk mempertahankan dan bahkan meningkatkan kinerjanya di kemudian hari. Namun apabila karyawan merasa kompensasi yang didapatkanya kurang sesuai dengan apa yang telah diberikan kepada organisasi, maka karyawan cenderung enggan untuk berusaha meningkatkan kinerjanya.

\section{d. Pengaruh DisiplinKerja, Lingkungan Kerjadan Kompensasi Terhadap Kinerja Pegawai.}

Disiplin kerja, Lingkungan Kinerja dan Kompensasi yang layak dan baik akan mendorong kinerja yang lebih baik kepada setiap pegawai yang mana setiap karyawan akan merasa nyaman dengan adanya disiplin kerja yang teratur, kemudian lingkungan kerja yang nyaman dan diikuti kompensasi yang layak akan membawa peningkatan kinerja karyawan dan akan membawa dampak kepada peningkatan kinerja total instansi. Kerangka konseptual merupakan model tentang bagaimana teori berhubungan dengan berbagai faktor yang telah diidentifikasi sebagai masalah yang penting. Dapat menjelaskan tentang adanya hubungan atau pengaruh variabel bebas yang terdiri dari disiplin kerja,lingkungan kerja dan kompensasi terhadap variabel yang tidak bebas yaitu kinerja karyawan. Kinerja pada dasarnya adalah sesuatu yang dilakukan dan atau tidak dilakukan karyawan sehingga mereka mempengaruhi seberapa banyak mereka memberikan kontribusi kepada organisasi termasuk pelayanan kualitas yang disajikan. Tuntutan-tuntutan yang tidak mampu dikendalikan oleh setiap karyawan ini akan menimbulkan ketegangan dalam diri karyawan dan jika tidak dapat diatasi maka karyawan tersebut akan mengalami penurunan semangat kerja dan disiplin kerja.Dari gagasan penelitian yang mengacu pada kajian teori, sehingga munculnya variabel-variabel yang digunakan dalam penelitian.Berikut merupakan kerangka pemikiran teoritis yang diambil dari pustakaan dan penelitian terdahulu. Adapun variabel Disiplin Kerja, Lingkungan Kerja dan Kompensasi adalah variabel bebas (X) sedangkan kinerja pegawai adalah variabel terikat (Y). Kerangka berpikir yang diajukan adalah mengenai pengaruhDisiplin Kerja, Lingkungan Kerja dan Kompensasi terhadap kinerja pegawai.

\subsection{Analisis Regresi Linier Berganda}

Tabel 1. Analisis Regresi Linier Berganda

\begin{tabular}{|c|c|c|c|c|c|c|}
\hline \multirow[b]{2}{*}{ Model } & & \multicolumn{2}{|c|}{ Unstandardized Coefficients } & \multicolumn{2}{|l|}{$\begin{array}{l}\text { Standardized } \\
\text { Coefficients }\end{array}$} & \multirow[b]{2}{*}{ Sig. } \\
\hline & & $\mathrm{B}$ & Std. Error & Beta & $\mathrm{T}$ & \\
\hline \multirow[t]{4}{*}{1} & (Constant) & 7.184 & 3.427 & & 2.096 & .042 \\
\hline & DISIPLIN KERJA & .084 & .213 & .082 & .396 & .694 \\
\hline & LINGKUNGAN KERJA & .132 & .111 & .145 & 1.191 & .240 \\
\hline & KOMPENSASI & .566 & .186 & .594 & 3.034 & .004 \\
\hline a. Depe & ndent Variable: KINERJA & & & & & \\
\hline
\end{tabular}

Berdasarkan data tabel diketahui persamaan regresi linear berganda adalah : Y-5,612 $+0,830 X_{1}+0,522 X_{2}$ Adapun penjelasannya dari persamaan linear berganda diatas adalah sebagai berikut:

a. Nilai konstanta, Nilai konstanta sebesar 7,184, hal ini menunjukkan bahwa variabel bebas(X) berupa disiplin kerja $\left(X_{1}\right)$ lingkungan kerja $\left(X_{2}\right)$ dan kompensasi $\left(X_{3}\right)$ mampu dan memberi kontribusi yang besar dalam mempengaruhi tentang kinerja pegawai (Y) sebesar kelipatan 7,184 dari variabel penelitian yang ada.

b. Variabel disiplin $\operatorname{kerja}\left(X_{1}\right)$ Nilai variabel disiplin kerja sebesar 0,84 artinya apabila terjadi kenaikan pada variabel $\left(X_{1}, X_{2}\right.$ dan $\left.X_{3}\right)$ bersifat konstan, maka kinerja pegawai (Y) juga akan ikut meningkat sebesar 0,84 demikian juga sebaliknya. Hal ini berarti bila disiplin kerja $\left(X_{1}\right)$, mengalami kenaikan sebesar kelipatan 1x maka kinerja pegawai (Y) juga akan ikut menigkat yaitu sebesar $8,4 \%$, demikian juga sebaliknya.

c. Variabel lingkungan kerja $\left(X_{2}\right)$, Nilai variabel disiplin kerja sebesar 0,132 artinya apabila terjadi kenaikan pada variabel $X_{2}$, dan $X_{1}, X_{3}$ bersifat konstan, maka kinerja pegawai (Y) juga akan ikut menigkat sebesar 0,132 demikian juga sebaliknya. Hal ini berarti bila lingkungan kerja $\left(X_{2}\right)$ mengalami kenaikan sebesar kelipatan $1 \mathrm{x}$ maka kinerja pegawai (Y) juga akan ikut meningkat yaitu 13,2\% demikian juga sebaliknya.

d. Variabel kompnsasi $\left(X_{3}\right)$, Nilai variabel disiplin kerja sebesar 0,566 artinya apabila terjadi kenaikan pada variabel $\left(X_{1}, X_{2}\right.$ dan $\left.X_{3}\right)$ bersifat konstan, maka kinerja pegawai $(Y)$ juga akan ikut meningkat sebesar 0,84 demikian juga 
sebaliknya. Hal ini berarti bila kompensasi $\left(X_{1}\right)$, mengalami kenaikan sebesar kelipatan 1x maka kinerja pegawai (Y) juga akan ikut menigkat yaitu sebesar $56,6 \%$, demikian juga sebaliknya

\subsection{Uji Hipotesis}

Uji Hipotesis Secara Parsial (Uji t), Uji statistik t pada dasarnya menunjukkan seberapa jauh pengaruh satu variabel independen (bebas) secara individual dalam menerangkan variasi variabel dependen (terikat). Dengan alat bantu SPSS statistic 17.0 for windows, Melihat nilai t dan nilai sig (2-taled) untuk mengetahui nilai t hitung dan nilai (sig). Ho diterima jika sig $>0,05$ atau Ho ditolak jika sig $<0,05$.

Tabel 2. Hasil uji hipotesis, variable disiplin kerja

\begin{tabular}{llll}
\hline $\mathrm{R}$ & $\mathrm{R}$ Square & $\begin{array}{l}\text { Adjusted } \\
\text { Square }\end{array}$ & \multicolumn{1}{l}{$\mathrm{R}$} \\
Std. Error of the Estimate \\
\hline .689 & .475 & .464 & 2.936 \\
\multicolumn{4}{l}{ The independent variable is DISIPLIN KERJA. } \\
\hline
\end{tabular}

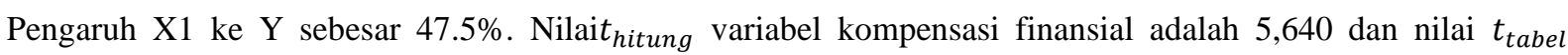
sebesar 1.660 maka nilai $t_{\text {hitung }} t_{\text {tabel }}(5,640<1,660)$ dan nilai sig $<0,05(0,000<0,05)$, sehingga dapat disimpulkan bahwa kompensasi finansial secara parsial berpengaruh signifikan terhadap kinerja pegawai yaitu sebesar 5.640.

Tabel 3. Hasil uji hipotesis, variable lingkungan kerja

\begin{tabular}{llll}
\hline $\mathrm{R}$ & $\mathrm{R}$ Square & $\begin{array}{l}\text { Adjusted } \\
\text { Square }\end{array}$ & $\mathrm{R}$ \\
.522 & .272 & .257 & 3.455
\end{tabular}

The independent variable is LINGKUNGAN KERJA.

Pengaruh X2 ke Y sebesar 27.2\%. Nilai $t_{\text {hitung }}$ variabel kompensasi finansial adalah 5,640 dan nilai $t_{\text {tabel }}$ sebesar 1.660 maka nilai $t_{\text {hitung }} t_{\text {tabel }}(5,640<1,660)$ dan nilai sig $<0,05(0,000<0,05)$, sehingga dapat disimpulkan bahwa kompensasi finansial secara parsial berpengaruh signifikan terhadap kinerja pegawai yaitu sebesar 5.640.

Tabel 4. Hasil uji hipotesis, variable kompensasi

\begin{tabular}{llll}
\hline $\mathrm{R}$ & $\mathrm{R}$ Square & $\begin{array}{l}\text { Adjusted } \\
\text { Square }\end{array}$ & $\mathrm{R}$ \\
Std. Error of the Estimate \\
\hline .745 & .555 & .546 & 2.701 \\
\multicolumn{4}{l}{ The independent variable is KOMPENSASI. } \\
\hline
\end{tabular}

Nilai $t_{\text {hitung }}$ variabel kompensasi finansial adalah 5,640 dan nilai $t_{\text {tabel }}$ sebesar 1.660 maka nilai $t_{\text {hitung }} t_{\text {tabel }}$ $(5,640<1,660)$ dan nilai sig $<0,05(0,000<0,05)$, sehingga dapat disimpulkan bahwa kompensasi finansial secara parsial berpengaruh signifikan terhadap kinerja pegawai yaitu sebesar 5.640

\section{$4.3 \mathrm{Uji}$ f}

Uji secara simultan (F), Uji-f (uji simultan) dilakukan untuk melihat secara bersama-sama (serempak) pengaruh secara positif dan signifikan dari variable bebas yaitu Disiplin Kerja, $\left(X_{1}\right)$ Lingkungan $\operatorname{Kerja}\left(X_{2}\right)$, dan Kompensasi $\left(X_{3}\right)$ terhadap kinerja Karyawan sebagai variabel terikat $(\mathrm{Y})$ sebagaimana yang terlihat pada tabel berikut:

Tabel 4. Hasil uji $\mathrm{f}$

\begin{tabular}{|c|c|c|c|c|c|c|}
\hline \multicolumn{2}{|c|}{ Model } & \multicolumn{2}{|c|}{ Sum of Squares Df } & \multirow{2}{*}{$\begin{array}{l}\text { Mean Square } \\
151.018\end{array}$} & \multirow{2}{*}{$\begin{array}{l}\mathrm{F} \\
20.754\end{array}$} & \multirow{2}{*}{$\frac{\text { Sig. }}{.000^{\mathrm{a}}}$} \\
\hline 1 & Regression & 453.053 & 3 & & & \\
\hline & Residual & 334.727 & 46 & 7.277 & & \\
\hline & Total & 787.780 & 49 & & & \\
\hline
\end{tabular}

Berdasarkan data tabel tersebut memperlihatkan bahwa nilai $F_{\text {hitung }}$ adalah 20,754 dengan tingkat signifikan 0,000. Sedangkan. Nilai $F_{\text {tabel }}$ pada tingkat signifikan 95\% $(\alpha=0,05)$ adalah 3,094 dimana ( $F_{\text {hitung }}>$ 
$\left.F_{\text {tabel }}\right)$ sehingga 91,605 > 3,094 dan nilai sig $<0,05(0,000<0,05)$ dengan demikian, secara simultan terdapat pengaruh yang signifikan antara disiplin kerja, lingkungan kerja dan kompensasi terhadap kinerja pegawai.

\section{KESIMPULAN}

Berdasarkan hasil penelitian dan pembahasan yang telah disajikan, maka penulis akan mencoba untuk menarik kesimpulan terdapat pengaruh yang tidak signifikan antara Disiplin Kerja terhadap Kinerja Pegawai di Universitas

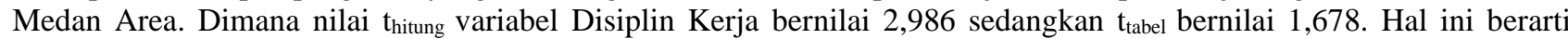
$t_{\text {hitung }}>t_{\text {tabel }}$ yaitu 2,986 $>1,678$ dengan nilai signifikan 0,05. Terdapat pengaruh yang tidak signifikan antara Lingkungan Kerja terhadap Kinerja Pegawai di Universitas Medan Area.Dimana nilai thitung variabel Lingkungan Kerja bernilai 2,191 sedangkan $t_{\text {tabel }}$ bernilai 2,191 . Hal ini berarti $t_{\text {hitung }}>t_{\text {tabel }}$ yaitu 3,034 $>1,678$ dengan nilai signifikan 0,05 . Terdapat pengaruh yang signifikan antara Kompensasi terhadap Kinerja Pegawai di Universitas Medan Area. Dimana nilai thitung variabel Kompensasi bernilai 3,034 sedangkan $t_{\text {tabel }}$ bernilai 1,678. Hal ini berarti $t_{\text {hitung }}>t_{\text {tabel }}$ yaitu 3,034 $>1,678$ dengan nilai signifikan 0,05. Secara simultan terdapat pengaruh yang signifikan antara Disiplin Kerja, Lingkungan Kerja dan Kompensasi secara bersama-sama terhadap kinerja karyawan diUniversitas Medan Area. Dimana nilai $F_{\text {hitung }}$ variabel Disiplin Kerja, Lingkungan Kerja dan Kompensasi bernilai 20,754 sedangkan $\mathrm{F}_{\text {tabel }}$ bernilai 2,81. Hal iniberarti $\mathrm{F}_{\text {hitung }}>$ $\mathrm{F}_{\text {tabel }}$ yaitu 20,754 >2,81. Koefisien determinasi (Rsqure) sebesar 0,575 dan nilai (Adjusted R Square) yaitu 0,547 atau $54,7 \%$ artinya variabel ( Disiplin Kerja, Lingkungan Kerja dan Kompensasi), penelitian mampu menjelaskan tentang Kinerja Pegawai sebesar 54,7\% sedangkan sisanya 45,3\% dipengaruhi oleh variabel lain diluar penelitian ini seperti variabel gaya kepemimpinan, motivasikerja, kepuasankerja, dan iklim kerja.

\section{DAFTAR PUSTAKA}

Ardhana,2011 I Komang, Ni Wayan Mujiati, dan, I Wayan Mudhiarta Utama, Manajemen Sumber Daya Manusia, Edisi Pertama, Yogyakarta: Graha Ilmu, 2011.

Benardin dan Russel. 2005. Manajemen Sumber Daya Manusia, Diterjemahkan oleh Bangbang Sukoco. Bandung : Penerbit Armico.

Dharma . Surya. 2005.Manajemen Kinerja :Falsafah Teori dan Penerapannya. Jakarta :Penerbit Pustaka Pelajar .

Handoko T . Hani 2003 Manajemen Personalia dan Sumber Daya Manusia, Edisi Kedua, Cetakan Keenam Belas, BPFE-UGM, Yogyakarta.

Hariandja, Marihot T.E., 2005. Manajemen Sumber Daya Manusia, Cetakan Ketiga, Penerbit Grasindo.

Hasibuan Melayu SP. 2005. Manajemen Sumber Daya Manusia, Edisi Revisi, Cetakan Kesembilan, Penerbit PT. Bumi Aksara, Jakarta.

Hasibuan Melayu SP. 2012. Manajemen Sumber Daya Manusia, Edisi Revisi, Cetakan Keenambelas, Penerbit PT. Bumi Aksara, Jakarta.

Mahmudi. 2007. Manajemen Kinerja Sektor Publik. Yogyakarta : Unit Penerbit dan Percetakan. Sekolah Tinggi Ilmu Manajemen YKPN.

Mangkunegara, AA. Anwar Purba, 2006. Manajemen Sumber Daya Manusia Perusahaan, Remaja Rosdakarya, Bandung.

Mahsum, Prof. Dr. MS, 2009. Manajemen Sumber Daya Manusia, Penerbit : PT Raja Grafindo Persada.

Mathis, Robert L. Dan Jhon H. Jakcson. 2012. Manajemen Sumber Daya Manusia. Jakarta : Penerbit Salemba Empat

Mondy, R. Wayne, 2008. Manajemen Sumber Daya Manusia, Edisi Kesepuluh, Jilid I, Penerbit Erlangga, Jakarta.

Nitisimito, Alex S. 2009. Manajemen Personalia. Yogyakarta : Ghalia Indonesia.

Ria Amelia Sinaga .2016. Pengaruh Disiplin Kerja dan Lingkungan Kerja Terhadap Kinerja Karyawan di PT. AngkasaPura II Medan.

Panggabean, Mutiara S. 2006. Manajemen Sumber Daya Manusia. Cetakan Pertama. Ghalia Indonesia.

Puspanegara, lady. 2009. Pengaruh Motivasi, Kompensasi dan Kemampuan Terhadap Kerja Pegawai Negeri Sipil (PNS) di Lingkungan Dinas Pertanian, Peternakan dan Perikanan Kabupaten Lampung Utara.

Sedermayanti. 2009. Sumber Daya Manusia Dan Produktivitas Kerja. Bandung : Mandar Maju.

Simanjuntak, Payaman J. Manajemendan Evaluasi Kinerja, Jakarta: Penerbit Fakultas Ekonomi Universitas Indonesia, 2011.

Simamora.H. 2006. Manajemen Sumber Daya manusia. Jakarta : PT. Gramedia Pustaka Utama.

Siagian, Sondang. Manajemen Sumber Daya Manusia, Cetakan Ketiga Belas, Jakarta: Bumi Aksara, 2006.

Sugiyono. 2010. Metode Penelitian Bisnis ( Pendekatan Kuantitatif, Kualitatif dan R\&D ). Cetakan Keduabelas. Bandung : Alfabeta.

Sugiyono. 2015. Metode Penelitian Bisnis ( Pendekatan Kuantitatif, Kualitatif dan R\&D ). Cetakan Kelimabelas. Bandung : Alfabeta.

Sutrisno, Edy, 2010. Manajemen Sumber Daya Manusia, Andi Offset, Yogyakarta.

Stoner, James A F., 2009. Dasar-Dasar Manajemen, Terjemehan Alfonsus Sirait, Jilid II, Penerbit Erlangga, Jakarta.

Wursanto, Drs. Ig. 2009. Manajemen Kepegawaian, Penerbit : Pustaka Dian, Jakarta. 